\title{
Survival Among Children and Adults With Sickle Cell Disease in Belgium: Benefit From Hydroxyurea Treatment
}

\author{
Phu Quoc Lê, MD, ${ }^{1}$ Béatrice Gulbis, MD, PhD, ${ }^{2}$ Laurence Dedeken, $M D,{ }^{1}$ Sophie Dupont, $M D_{,}{ }^{3}$ Anna Vanderfaeillie, $\mathrm{MD}_{,}{ }^{4}$ \\ Catherine Heijmans, MD, ${ }^{1,5}$ Sophie Huybrechts, MD, ${ }^{1}$ Christine Devalck, MD, ${ }^{1}$ André Efira, MD, ${ }^{6}$ \\ Marie-Franç oise Dresse, MD, PhD, ${ }^{7}$ Laurence Rozen, ${ }^{8}$ Fleur Samantha Benghiat, $\mathrm{MD}, \mathrm{PhD}^{9}$ and Alina Ferster, $\mathrm{MD}^{1}$
}

\begin{abstract}
Objective. To evaluate the survival of patients with sickle cell disease (SCD) recorded in the Belgian SCD Registry and to assess the impact of disease-modifying treatments (DMT). Method. The Registry created in 2008 included patients of eight centers. All available data in 2008 were retrospectively encoded in the database. After 2008 and until 2012, all data were recorded prospectively for already registered patients as well as newly diagnosed subjects. Data were registered from neonatal screening or from diagnosis (first contact) until last follow-up or death. Data included diagnosis, demography, and outcome data. Results. We collected data from 469 patients over a 5,110 patient years (PY) follow-up period. The global mortality rate was low (0.25/100 PY), although 13 patients died (2.8\%) and was similar between children, adolescents (10-18 years), and young adults $(P=0.76)$. Out of the cohort, 185 patients received
\end{abstract}

hydroxyurea at last follow-up (median duration of treatment: 10.3 years), 90 underwent hematopoietic stem cell transplantation (HSCT), 24 were chronically transfused, and 170 had never had any DMT. Hydroxyurea showed significant benefit on patients outcome as reflected by a lower mortality rate compared to transplanted individuals or people without $\operatorname{DMT}(0.14,0.36$, and 0.38 per $100 \mathrm{PY}$, respectively) and by higher Kaplan-Meier estimates of 15 year survival $(99.4 \%)$ compared to HSCT $(93.8 \% ; P=0.01)$ or no DMT groups $(95.4 \% ; P=0.04)$. Conclusion. SCD mortality in Belgium is low with no increase observed in young adults. Patients treated with hydroxyurea demonstrate a significant benefit in survival when compared to those without DMT or transplanted. Pediatr Blood Cancer 2015;62:1956-1961. (C) 2015 Wiley Periodicals, Inc.

Key words: hydroxyurea; mortality; sickle cell disease; survival

\section{INTRODUCTION}

In Western countries, mortality among children with sickle cell disease (SCD) has decreased in the last few decades. Major advances in this field are the result of the implementation of preventive measures and mainly linked to the introduction in the 1980s of the systematic penicillin prophylaxis[1] and vaccinations to prevent pneumococcal and Haemophilus influenza type b diseases.[2-7] Systematic newborn screening, parents' education, and comprehensive care programs have also greatly contributed to reduce childhood mortality.[8] More recently transcranial Doppler ultrasonography screening allows identifying asymptomatic patients at high risk for stroke.[9] In them, chronic transfusion support is now recognized as a major breakthrough in stroke prevention.[10,11] From several clinically based series we know that more than $95 \%$ of children with SCD are expected to reach adulthood.[12-16] The other 5\% dies mainly from acute chest syndrome (ACS), sepsis, splenic sequestration, stroke, and aplastic crisis. For those who reach adulthood, an additional cause of death is end-stage organ failure.[17-21]

Survival in the Belgian population with SCD has never been studied. A national database recording these patients was created in 2008 and offers a unique tool to address this question. The introduction, more than 20 years ago in Belgium, of treatments such as hydroxyurea (HU) and hematopoietic stem cell transplantation (HSCT), but also the partial implementation of a newborn screening program, might have modified this survival rate. The objectives of this study were to evaluate the mortality rate and the causes of death among the registered Belgian patients with SCD, and to determine the possible impact of disease-modifying therapies on that mortality rate.

\section{PATIENTS AND METHODS}

\section{Setting}

No official national registry of patients with SCD existed in Belgium. In October 2008, under the auspices of the Belgian
Hematological Society, members of its Red Blood Cells committee decided to set up a SCD patients' database. Treating hematologists were invited to participate on a voluntary basis and to register their patients into the national database. The database included all patients who regularly followed in the clinical center. The Belgian SCD Registry currently includes patients from eight centers either adult or pediatric. Among them, two are secondary and six are

Abbreviations: ACS, acute chest syndrome; CI, confidence interval; DMT, disease-modifying treatment; Hb, hemoglobin; HSCT, hematopoietic stem cell transplantation; HU, hydroxyurea; NSP, newborn screening programme; PY, patient-year; SCD, sickle cell disease; SE, standard error; US, United States of America; VOC, vaso occlusive crisis

${ }^{1}$ Hemato-Oncology Unit, Hôpital Universitaire des Enfants Reine Fabiola, U.L.B., Brussels, Belgium; ${ }^{2}$ Department of Clinical Chemistry, Hôpital Erasme, U.L.B., Brussels, Belgium; ${ }^{3}$ Hemato-Oncology Unit, Cliniques Universitaires Saint Luc, Brussels, Belgium; ${ }^{4}$ Department of Pediatrics, Hôpital Saint-Pierre, U.L.B., Brussels, Belgium; ${ }^{5}$ Department of Pediatrics, Hôpital de Jolimont, La Louvière, Belgium; ${ }^{6}$ Hemato-Oncology Unit, Hôpital Universitaire Brugmann, U.L.B., Brussels, Belgium; ${ }^{7}$ Hemato-Oncology Unit, Hôpital Régional de la Citadelle, ULg, Liège, Belgium; ${ }^{8}$ Laboratory of Hematology, CHUBrugmann, Hôpital Universitaire des Enfants Reine Fabiola, U.L.B., Brussels, Belgium; ${ }^{9}$ Hemato-Oncology Unit, Hôpital Erasme, U.L.B., Brussels, Belgium

Grant sponsor: Fonds IRIS-Recherche Brussels; Grant sponsor: Novartis Pharma Belgium

Conflicts of interest statement: The authors have no competing interests.

*Correspondence to: Phu Quoc Lê, Department of Hemato-oncology, Hôpital Universitaire des Enfants Reine Fabiola, 15 Avenue Jean Joseph Crocq, 1020 Brussels, Belgium. E-mail: phuquoc.le@huderf.be Received 14 January 2015; Accepted 22 April 2015 
tertiary care centers. Six of them provide care to children and two to adult patients.

In Belgium, a universal newborn screening program (NSP) for hemoglobinopathies began in Brussels Region in 1994 and in Liège Region in 2001. Today, neonatal screening is thus now offered to about one-third of Belgian newborns.

Once patients with SCD were identified, their regular follow-up in the participating centers was applied according to the policy of each center. All the patients were prescribed oral antibiotic prophylaxis at least up to five years of age. The usual immunization schedules according to the national recommendations were provided, including conjugate vaccines against Haemophilus influenzae type b (four doses) since 1994 and conjugated Streptococcus pneumoniae (three doses) since 2004. Starting in 1999, transcranial Doppler ultrasonography has been progressively included in the regular follow-up. Disease modifying therapies (DMT) such as hydroxyurea,[22-25] chronic transfusion, and hematopoietic stem cell transplantation[26-30] were introduced according to each center's policy but following the usual indications that have been detailed in previous international publications. [25,31-33] National recommendations on SCD management were only recently implemented in Belgium. In almost all centers, the management of the patients was implemented gradually as a comprehensive care program with emphasis on education, prevention, and patient empowerment.

\section{Data Collection}

A secured computer-based database for all patients with SCD followed in Belgium was created in 2008. For this study, the database was locked in December 2012 and the first author of the study collected all data. Each local ethics committee approved data collection and the registry according to the Declaration of Helsinki. To ensure patient confidentiality, data were processed in compliance with legal requirements and privacy guidelines. Informed consent was obtained from all patients (or their parents/legal guardians). For patients who died before 2008, retrospective data collection was used. Patients' data that predates 2008 were extracted from the medical records while from 2008 data were directly entered into the database. Data were collected either from birth or from the diagnosis depending on whether the patients benefited from the newborn screening program or not, and until the last follow-up visit, or death of the patient. The database includes diagnosis (date, method, and genotype), demographic data, SCDrelated events, hospitalizations, immunizations, steady-state biological parameters, data on chronic organ damage (i.e., cerebral vasculopathy, renal failure), treatments, vital status, and cause of death. For patients lost to follow-up, last available data are from the last visit. After HSCT, only vital status was recorded as well as the cause of death if applicable. Patients transplanted before 1985 without complete data set or not living in Belgium before HSCT were not included in this analysis $(\mathrm{n}=10)$.

\section{Statistical Analysis}

Categorical and continuous variables were analyzed with Graphpad Prism ${ }^{\mathbb{R}}$ software 5.0 (Graphpad Software, Inc., San Diego, CA). Kruskal-Wallis test was used to compare continuous data of multiple groups expressed as median whereas Dunn's Multiple comparison test was used to compare data of pairs of Pediatr Blood Cancer DOI 10.1002/pbc groups. $\chi^{2}$ and Fisher's tests were used to compare data expressed as proportions.

Kaplan-Meier and their 95\% confidence interval (95\%CI) were calculated. Group survivals were compared by the log-rank test. The different survival curves of HU, HSCT, and no DMT were compared by the same log-rank test and the $P$-value was adjusted for multiple testing by the Bonferroni method. Because patients may have had successive treatments, we tested with a Cox regression model if a time-varying effect was significantly associated with survival. A $P$-value less than 0.05 for sociodemographic differences between the groups was considered statistically significant. Statistical significance was attained when a $P$-value was less than 0.0167 for multiple testing by the Bonferroni method.

\section{RESULTS}

Up to December 2012, 469 patients were registered in the database. The main characteristics of the patients are depicted in Tables I and II, respectively. Among the 5,110 patient-years of follow-up, 1,242 accounted for patients diagnosed by newborn screening. The global mortality rate was $0.25 / 100$ patient-years; 13 patients died $(2.8 \%)$. The mortality rate of the neonatal screened cohort was $0.16 / 100$ patient-years and was $0.28 / 100$ patient-years in the non-neonatal screening cohort $(P=0.67)$. Mortality rate was similar between children, adolescents (10-18 years), and young adults $(P=0.76)$. All deaths occurred in HbSS patients, five after HSCT (three from acute transplant related toxicity, one from secondary acute myeloblastic leukemia after chronic graft vs. host disease four years after transplantation, and one unexplained death occurred more than seven years post HSCT), and eight were related to an acute event (three from hemorrhagic strokes, one from sepsis due to $S$. pneumoniae, one from aplastic crisis, one from cardiac failure associated with tetralogy of Fallot, one sepsis associated with leg ulcer, and one infection during travel in Africa). All patients were under antibiotic prophylaxis. Three patients who died from hemorragic stroke were not followed by routine transcranial Doppler; their vasculopathy was inaugural (Table III).

Ninety patients underwent HSCT. Median age at transplantation was 6.9 years (range: 1-19 years). Among the non-transplant

TABLE I. Characteristics of the SCD Population, Follow-Up Duration, and Mortality Rate According to Age at Last Follow-Up and Genotype

\begin{tabular}{|c|c|c|c|}
\hline & $\mathrm{N}$ & $\begin{array}{c}\text { Follow-up (patient } \\
\text { year) }\end{array}$ & $\begin{array}{c}\text { Mortality rate } \\
\text { (/100 patient } \\
\text { years) }\end{array}$ \\
\hline $\begin{array}{l}\text { All cohort } \\
\text { (males) }\end{array}$ & $\begin{array}{c}469 \\
(223)\end{array}$ & 5,110 & 0.25 \\
\hline$<10$ years & 186 & 974 & 0.41 \\
\hline $10-18$ years & 144 & 1,557 & 0.32 \\
\hline$>18$ years & 139 & 2,579 & 0.16 \\
\hline \multicolumn{4}{|l|}{ Genotypes } \\
\hline $\mathrm{HbSS}+\mathrm{HbS}^{\circ}$ & 423 & 4,749 & 0.27 \\
\hline$<10$ years & 163 & 846 & 0.47 \\
\hline $10-18$ years & 128 & 1,411 & 0.35 \\
\hline$>18$ years & 132 & 2,492 & 0.16 \\
\hline $\mathrm{HbSC}$ & 36 & 292 & 0 \\
\hline $\mathrm{HbS} \beta^{+}$ & 7 & 54 & 0 \\
\hline
\end{tabular}


TABLE II. Data on Follow-Up and Mortality According to Last Treatment

\begin{tabular}{|c|c|c|c|c|}
\hline Patients & No DMT & $\mathrm{CT}$ & HU & HSCT \\
\hline $\mathrm{N}$ & 170 & 24 & 185 & 90 \\
\hline Median age at diagnosis years (range) & $0(0-33)$ & $1.0(0-9.7)$ & $1.2(0-35)$ & $1.9(0-14.5)$ \\
\hline Median age at last FU years (range) & $7.6(1.0-53)$ & $12.2(2.6-27)$ & $13.7(2.1-44)$ & $16.9(5.1-38)$ \\
\hline Median FU years (range) & $6.1(0.1-49)$ & $10.9(2.3-25)$ & $10.4(0.1-35)$ & $14.5(1.3-32)$ \\
\hline Follow-up (PY) & 1,299 & 282 & 2,126 & 1,403 \\
\hline Lost of FU & 16 & 0 & 10 & 4 \\
\hline Deaths & $5(2.9 \%)$ & 0 & $3(1.6 \%)$ & $5(5.6 \%)$ \\
\hline Mortality-rate (/100 PY) & 0.38 & 0 & 0.14 & 0.36 \\
\hline
\end{tabular}

FU, follow-up; PY, patient-years; DMT, disease modifying treatment; CT, chronic transfusion; HU, hydroxyurea; HSCT, hematopoietic stem cell transplantation. Median age at diagnosis, $P$-value $<0.0001$ : No DMT versus $\mathrm{HU}^{* * * *}$ and No DMT versus $\mathrm{HSCT}^{* * * *}$. Median age at last FU, $P$-value $<0.0001$ : No DMT versus HU ${ }^{* * *}$, No DMT versus HSCT ${ }^{* * *}$, HU versus HSCT ${ }^{*}$. Median FU, $P$-value $<0.0001$ : No DMT versus HU***, No DMT versus HSCT $^{* * * *}$, No DMT versus $\mathrm{CT}^{*}$, HU versus HSCT ${ }^{* *}$.

patients, 185 were on $\mathrm{HU}$ at last follow up for a median duration of 10.3 years (range: $0.1-35$ years) and 24 were on chronic transfusion regimen (4 after $\mathrm{HU}$ treatment). The reasons for $\mathrm{HU}$ prescriptions were $\geq 2$ vaso occlusive crisis (VOC) per year requiring hospitalization (110 patients), $\geq 2$ episodes of ACS $(n=33)$, recurrent splenic sequestration $(n=6)$, recurrent dactylitis $(n=7)$, stroke or transient ischemic attack $(\mathrm{n}=2)$ with red blood cell alloimmunization impairing chronic transfusion, and abnormal transcranial Doppler ultrasonography $(\mathrm{n}=27)$. The remaining 170 patients never received DMT. Patients treated with HU were significantly older at diagnosis, had a longer follow-up, and lower death rate/100 patient years than those with no DMT. Patients who underwent HSCT had not a more severe clinical disease than those treated with HU. The indications to start HU treatment or to perform HSCT were VOC, respectively, in $110 / 185$ and $40 / 90$ patients $(P=0.02)$, recurrent ACS in $33 / 185$ and $17 / 90$ patients $(P=0.87)$, and abnormal blood flow velocities in cerebral arteries in $27 / 180$ and 13/90 $(P=1)$. Two patients have had stroke in both groups.

The 15-year overall survival of the entire cohort was $96.9 \%$ (95\% CI: 95-99; $\mathrm{SE}=0.95 \%$ ) but varied significantly according to the treatment given (Fig. 1). Mortality rates for HU, no DMT, and HSCT groups were $0.14,0.38$, and 0.36 per 100 patient years, respectively. Fifteen-year overall survival for patients having never received DMT nor HSCT was 95.4\% (95\%CI: 91-100; $\mathrm{SE}=2.5 \%$ ) while for patients treated with HU or HSCT, overall survival was respectively $99.4 \%$ (95\% CI: $98-100 ; \mathrm{SE}=0.6 \%)$, and $93.8 \%(95 \%$ CI: $89-99 ; \quad \mathrm{SE}=2.7 \%$ ). Kaplan-Meier estimates of survival indicated that the three survival curves (HU, HSCT, and no DMT) are different from each other $(P=0.046)$. Improved survival was associated with HU compared with no DMT $(P=0.04)$ or with HSCT $(P=0.01)$ while overall survival in HSCT patients was not significantly different from patients without DMT $(P=0.66)$. Adjusted $P$-values for multiple testing remained significant with $P=0.013$ and $P=0.003$ for HU compared with no DMT or to HSCT, respectively. No significant time-varying effect of successive treatments could be found $(P=0.79)$.

\section{DISCUSSION}

Thanks to an observational multicenter design, the present work provides important information about the outcome of a national Belgian SCD cohort. Both children and adults diagnosed by newborn screening or during a clinical event were included in the study and data were collected prospectively or retrospectively. Our main findings consisted in a globally low-mortality rate among the entire cohort that did not significantly increase above 18 years of

TABLE III. Causes of Death Reported in the National Belgian Database

\begin{tabular}{|c|c|c|c|c|c|}
\hline Patient & Sex & Genotype & Age at event & Year of death & Cause \\
\hline 1 & $\mathrm{~F}$ & SS & 11years 9 months & 1992 & Obliterans bronchiolitis/MOF on day103 post HSCT \\
\hline 2 & $\mathrm{~F}$ & SS & 22 years 4 months & 1994 & Sepsis-Leg ulcer \\
\hline 3 & M & SS & 7 years & 1995 & $\begin{array}{l}\text { Secondary leukemia after extensive chronic graft } \\
\text { versus host disease } 4.5 \text { years after HSCT }\end{array}$ \\
\hline 4 & M & SS & 17 years 7 months & 1996 & Unknown-Found dead at home 7 years after HSCT \\
\hline 5 & $\mathrm{~F}$ & SS & 18 months & 1996 & Cardiopulmonary arrest_-Severe acute anemia episode \\
\hline 6 & M & SS & 4 years 7 months & 1999 & Cardiac failure-Tetralogy of Fallot \\
\hline 7 & M & SS & 26 months & 2000 & Septic shock on $S$. pmeumoniae septicaemia \\
\hline 8 & $\mathrm{~F}$ & SS & 14 years 9 months & 2000 & Hemorrhage diathesis/MOF on day 56 post HSCT \\
\hline 9 & M & SS & 23 years 9 months & 2003 & Unknown-Died during holidays in Africa \\
\hline 10 & M & SS & 14 years 3 months & 2007 & Meningeal hemorrhage \\
\hline 11 & $\mathrm{~F}$ & SS & 18 years 3 months & 2007 & Cerebral hemorrhage \\
\hline 12 & $\mathrm{~F}$ & SS & 18 years 9 months & 2007 & Cerebral aneurysm rupture \\
\hline 13 & M & SS & 15 years 1 months & 2011 & Cerebral hemorrhage on day 18 post HSCT \\
\hline
\end{tabular}

MOF, multiple organ failure; HSCT: hematopoietic stem cell transplantation. 


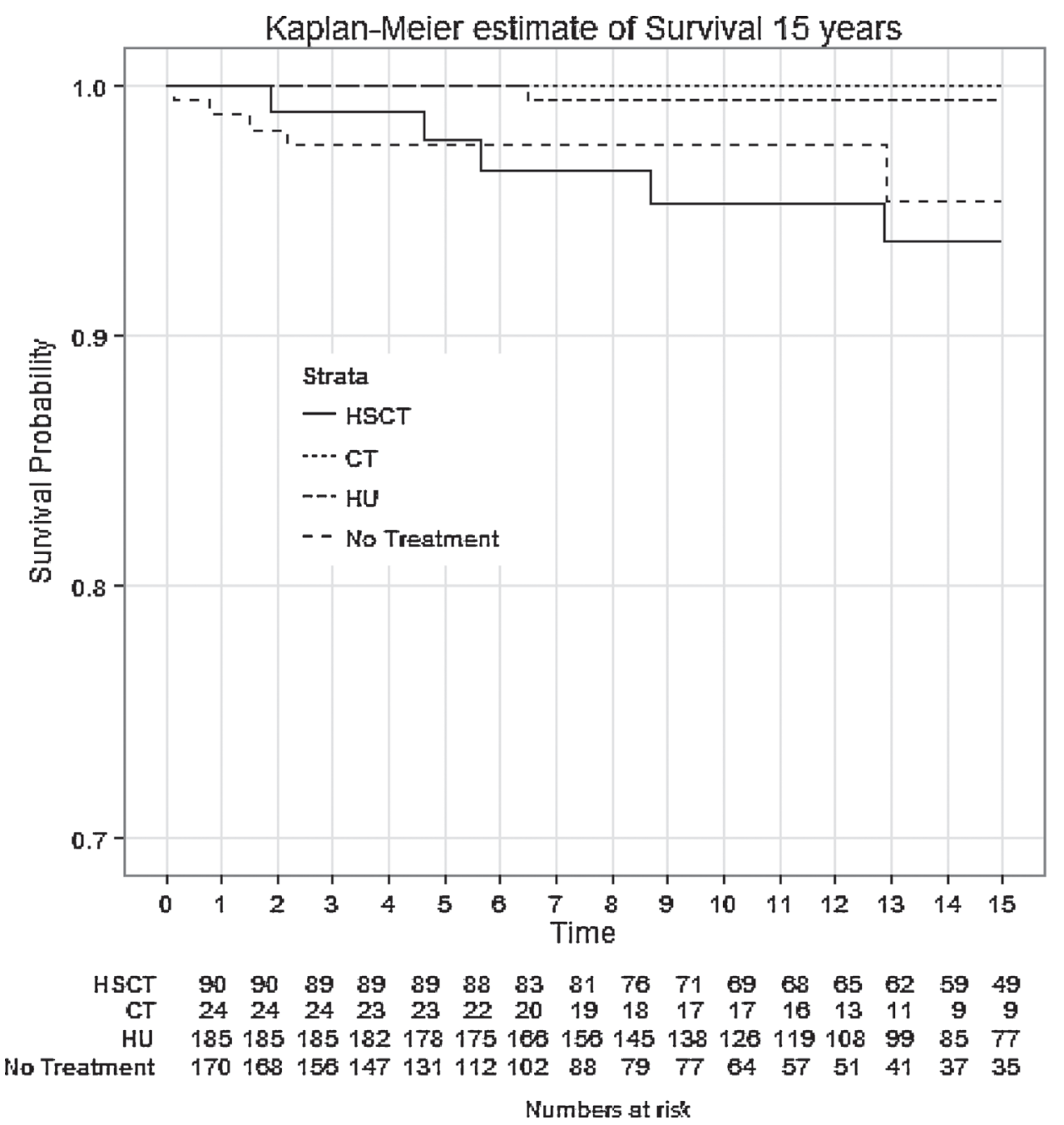

Fig. 1. Survival according to treatment. Kaplan-Meier curves show the 15 -year overall survival for patients under hydroxyurea (HU), chronic transfusion (CT), transplanted (HSCT), and who do not received disease modifying therapy (DMT). The four survival curves are not significantly different from each other $(P=0.07)$. Patients receiving HU have a significantly better survival in comparison to those without DMT treatment $(P=0.04)$ or those who have been transplanted $(P=0.01)$. There was no significant difference in survival among transplanted and untreated patients $(P=0.66)$.

age. Moreover, we observed a positive impact of HU treatment on patients' survival rate although the subjects under HU treatment showed a longer length of follow-up and were older at the time of SCD diagnosis. A possible explanation for this latter observation was that HU prescription was mostly supported by the succession of SCD events overtime instead of resulting from a systematic use in young children as recommended by the recent National Institutes of Health guidelines.[34]

Our observed overall mortality rate of 0.25 per 100 patient years is low. The mortality rates published and issued from single or multicenter cohort studies are $0.13,0.52$, and 1.1 per 100 patient years for the East London cohort, the Dallas Newborn Cohort, and the Cooperative Study on Sickle Cell Disease, respectively.[14-16,35] These variable rates have been attributed to genetic differences in the populations studied and also to the successful implementation of a comprehensive care programme.[15,35] Compared to the East London cohort, our population consisted of fewer HbSC individuals (7\% vs. $25 \%$ ), a higher proportion of patients originating from Pediatr Blood Cancer DOI 10.1002/pbc
Central Africa, a region known to have more severe clinical SCD forms ( $73 \%$ in our cohort), a higher median age at last follow-up (12.3 years vs. 7.8 years), and a higher total follow-up duration $(5,110$ patient years vs. 2,158 patient years). As reported in the East London cohort no deaths occurred in SC individuals with the current followup.

During the last few decades, other interesting data were provided from population-based analysis using national data derived from death certificates in the United States. It highlights the age-specific changes in mortality over time. As reported by Yanni et al. (2009), from 1983-1986 to 1999-2002, the relative mortality rate dropped significantly in children younger than 10 years (and mainly under the age of four), but remained unchanged in older ones. This survival improvement was concurrent with the introduction of pneumococcal conjugate vaccination suggesting that in addition to penicillin prescription, conjugate vaccines might have strongly contributed to prevent deaths from invasive pneumococcal infections.[3] A more recent 
evaluation of mortality rates among United States children and adults with SCD between two periods of time, i.e., 1979-1998 and 1999-2009, confirmed the significant decline in the mortality rate among children but also among adolescents over time.[6] Implementation of newborn screening, infection prophylaxis, regular visits, and comprehensive care, as well as primary stroke prevention policy most probably had an effect in the latter period. However in adults no survival improvement was observed.[36] The more recent population-based studies in the United States still continue to show a significantly higher rate of deaths attributable to sickle cell disease in young adults compared to children or teenager. The difficult transition from pediatric to adult care with loss of comprehensive care has been claimed to be the major risk factor, but poor socio-economic conditions, different cultural and educational factors probably also have a role in that deterioration. The present study, though limited, did not confirm in the Belgian population the dramatic increase in SCD-related mortality among young adults as observed in the United States.[4,36] This suggests that the transition may occur in better conditions with superior access to health care under the Belgian health care system compared to that available in the United States. Indeed the Belgian national healthcare system contributes in a same way to the medical costs irrespective of patient age and employment. Furthermore, Belgium is a small country with a high-medical density, a strong hematologists network that shares standard of care, and patients who have direct access to specialists and secondary or tertiary hospitals.

In addition to crude data on SCD mortality in Belgium, our analyses provide information on specific outcome according to therapeutic interventions. Hydroxyurea has been well described and studied for more than two decades in adults and children. [22,23,25,37-39] More recently, the BABY-HUG's study[38,39] showed evidence of safety and efficacy data for HU therapy. It decreased pain, dactylitis, chest acute syndrome, and hospitalization, even for asymptomatic children. One considers that $\mathrm{HU}$ can be safely offered in very young children with SCD too.[34] By several mechanisms including increase in foetal hemoglobin production, red cell hydration, reduction of the neutrophil, and the reticulocyte counts, reduction of vascular adhesion molecules expression, reduction of bone marrow cellularity, and improvement of nitric oxide bioavaibility, it reduces the clinical severity of SCD course. Actually, it is significantly associated with reduction of acute pain and ACS events in children and adults and might slow down the development of organ dysfunction. The double blind, randomized controlled Multicenter Study of Hydroxyurea trial provided the first data on clinical efficacy of HU.[40] Adult patients with severe SCD should have been treated for two years but clinical improvement for patients on HU being much higher than for those without this treatment, the trial was stopped early. After its closure, patients could choose to stop, start, or continue HU. After a FU of 17.5 years, $43.1 \%$ of patients died ( $n=129 ; 4.4$ per 100 -patient years). Eightyseven percent of patients who died were never exposed to HU or took it for less than five years, suggesting that long-term use of HU reduces mortality.[41] Voskaridou et al. (2010) also observed the efficacy of long-term treatment HU in adult SCD patients. Significant improvement in 10-year overall survival was associated with HU treated compared to untreated ones who were not selected to receive $\mathrm{HU}$ as they have been considered as having a milder clinical disease. Significant benefit from HU treatment was observed in SS and $S / \beta^{\circ}$-thalassemia genotypes but not in $S / \beta^{+}$thalassemia genotype.
Lobo et al. (2013) were the first to investigate the impact of HU on mortality in children treated with HU. Children with severe disease, defined as those with more than three painful events requiring medical treatment, at least one episode of ACS, history of stroke or transient ischemic attack, one serious or recurrent episode of priapism, or an hemoglobin concentration $<60 \mathrm{~g} / \mathrm{l}$ on three separate occasions, were eligible for HU treatment at a dose of $20 \mathrm{mg} / \mathrm{kg} / \mathrm{day}$. One thousand seven hundred sixty patients were included and followed during 7,925 patient years. Compared with no treatment, in this study HU was highly beneficial: one death versus 36 (meaning 4.6 times less risk of dying), and a mortality rate per 100 patient years of $0.07\left(0.08 ; \mathrm{HbSS}\right.$ and $\left.\mathrm{HbS} \beta^{\circ}\right)$ versus 0.56 (0.59; $\mathrm{HbSS}$ and $\mathrm{HbS} \beta^{\circ}$ ).

Even if our Belgian cohort is not exclusively issued from newborn screening, the overall death rate is low $(0.25 / 100$ patient years) and remains low when considering only patients with SS and $S \beta^{\circ}$ genotypes $(0.27 / 100$ patient years). Several methodological biases are present in this partially retrospective study: no population-based study, incomplete, or unavailability of some files, loss of follow-up that occurred in 30 patients and no information if death occurred before the first contact in a center. Nevertheless, this probably does not alter our figures because (1) most patients have been followed since early childhood and for a long period of time cumulating 5,110 patient-years; (2) the followup during adulthood, when burden of mortality increases, accounted for 1,019 patient years; (3) data of the patients followed in the eight participating centers could be easily retrieved from their medical record and from the date of their diagnosis; and (4) our cohort represents a very large part of the Belgian population with SCD. In the absence of a national-based neonatal screening program and/or official registration based on diagnosis, the total number of SCD living in Belgium is unknown. A national inquiry performed in 2008 estimated the total number of patient with severe hemoglobinopathy to be 417 from whom $83 \%$ were sickle cell patients.[42] Our data concern thus a large majority of regularly monitored patients living in Belgium.

The 13 deaths reported in our cohort were related either to an acute event (8/13) or to HSCT toxicity (5/13). Cerebral hemorrhage remains the leading cause of death followed by infection. Mortality due to complications following HSCT accounted for more than onethird of all deaths resulting in lower survival in transplanted children when compared to those on HU. This might reflect some selection bias and differences in severity as HSCT is generally indicated in patients with a more severe clinical disease. Nevertheless, we could not demonstrate a more severe clinical disease in patients having been transplanted: they had significantly less VOC and similar history of ACS, stroke, or risk for stroke when compared to the HU group. The comparison of our relatively large group of patients treated with stem cell transplantation to those receiving other therapies failed to demonstrate any benefit of HSCT in terms of survival. However, death rate provides a very incomplete picture of the relative benefit of HSCT since long-term benefit may compensate the existing upfront mortality. Cure of SCD is now achieved in $95 \%$ of patients[29,30] and most of the successfully transplanted patients have improved quality of life. Prospective or cross-sectional comparisons of quality of life in the various treatment modalities could not be performed in the context of our registry and would provide strong data on the long-term benefits of transplantation compared to other treatment strategies. A longer follow-up, during adulthood when SCD morbidity and mortality 
increase $[43,44]$ is also mandatory to prove if previously transplanted patients will be advantaged for long-term survival compared to un-transplanted individuals treated with HU. The main limitations of our analysis were the combination of a prospective and retrospective design, the absence of populationbased data, the monocentric data collection, and the absence of standardization in treatment decision making.

In conclusion, whereas several studies have suggested a benefit from hydroxyurea treatment on children and adult sickle cell patients' survival, our study pointed out the positive impact during childhood. No benefit of HSCT versus HU on survival rate could be demonstrated after a 15 years median follow-up, but long-term, multicentric surveillance is required with help of the SCD Belgian National Registry. Finally, our results suggest that the availability of efficient alternatives in SCD treatment might render less systematic the need for HSCT that could be at least postponed in young patients with mild disease.

\section{ACKNOWLEDGMENTS}

The authors would like to thank Dr Scott Grosse for critically reviewing this manuscript. This work was supported by Fonds IRISRecherche Brussels, Belgium (2007) and an Educational Grant kindly provided from Novartis Pharma Belgium.

\section{REFERENCES}

1. Gaston MH,Verter JI, Woods G, Pegelow C, Kelleher J, Presbury G, Zarkowsky H, Vichinsky E, Iyer R Lobel JS, Diamond S, Holbrook CT, Gill FM, Ritchey K, Falletta JM, and for the Prophylactic Penicilli Study Group. Prophylaxis with oral penicillin in children with sickle cell anemia. A randomized trial. New Engl J Med 1986;314:1593-1599.

2. Davies EG, Riddington C, Lottenberg R, Dower N. Pneumococcal vaccines for sickle cell disease. Cochrane Database Syst Rev 2004;1:CD003885.

3. Adamkiewicz TV, Silk BJ, Howgate J, Baughman W, Strayhorn G, Sullivan K, Farley MH. Effectivenes of the 7-valent pneumococcal conjugate vaccine in children with sickle cell disease in the first decade of life. Pediatrics 2008;121:562-569.

4. Yanni E, Grosse SD, Yang Q, Olney RS. Trends in pediatric sickle cell disease-related mortality in the United States, 1983-2002. J Pediatr 2009;154:541-545.

5. Voskaridou E, Christoulas D, Bilalis A, Plata E, Varvagiannis K, Stamatopoulos G, Sinopoulou K, Balassopoulou A, Loukopoulos D, Terpos E. The effect of prolonged administration of hydroxyurea on morbidity and mortality in adult patients with sickle cell syndrome: Results of a 17-year, single-center tria (LaSHS). Blood 2010;115:2354-2363

6. Hamideh D, Alvarez O. Sickle cell disease related mortality in the United States (1999-2009). Pediat Blood Cancer 2013;60:1482-1486.

7. Lobo CL, Pinto JF, Nascimento EM, Moura PG, Cardoso GP, Hankins JS. The effect of hydroxycarbamide therapy on survival of children with sickle cell disease. Br J Haematol 2013:161:852-860.

8. Vichinsky E, Hurst D, Earles A, Kleman K, Lubin B. Newborn screening for sickle cell disease: Effect on mortality. Pediatrics 1988;81:749-755

9. Adams RJ, Nichols FT, Figueroa R, McKie V, Lott T. Transcranial Doppler correlation with cerebral angiography in sickle cell disease. Stroke 1992;23:1073-1077.

10. Adams RJ, McKie VC, Hsu L, Files B, Vichinsky E, Pegelow C, Abboud M, Gallagher D, Kutlar A, Nichols FT, Bonds DR, Brambilla D. Prevention of a first stroke by transfusion in children with sickle cell anemia and abnormal results on transcranial Doppler ultrasonography. New Engl J Med 1998:339:5-11.

11. Bernaudin F, Verlhac S, Arnaud C, Kamdem A, Chevret S, Hau I, Cö L, Leveillé E, Lemarchand E Lesprit E, Abadie I, Medejel N, Madhi F, Lemerle S, Biscardi S, Bardakdjian J, Galactéros F, Torres M, Kuentz M, Ferry C, Socié G, Reinert P, Delacourt C. Impact of early transcranial Doppler screening and intensive therapy on cerebral vasculopathy outcome in a newborn sickle cell anemia cohort. Blood 2011;117:1130-1140

12. Thomas C, Lemerle S, Bernaudin F, Feingold J, Guillou-Bataille M, Reinert P. Sickle cell anemia: Study of the pediatric mortality in Ile de France from 1985 to 1992. Arch Pédiatr 1996:3:445-451.

13. Neonato MG, Guilloud-Bataille M, Beauvais P, Bégué P, Belloy M, Benkerrou M, Ducrocq R, MaierRedeisperger M, de Montalembert M, Quinet B, Elion J, Feingold J, Girot R. Acute clinical events in 299 homozygous sickle cell patients living in France. Eur J Haematol 2000;65:55-164

14. Quinn CT, Rogers ZR, Buchanan GR. Survival of children with sickle cell disease. Blood 2004;103:4023-4027.

15. Telfer P, Coen P, Chakravorty S, Wilkey O, Evans J, Newell H, Smalling B, Amos R, Stephens A, Roger D, Kirkham F. Clinical outcomes in children with sickle cell disease living in England: A neonatal cohort in East England. Haematologica 2007;92:905-912.

16. Quinn CT, Rogers ZR, McCavit TL, Buchanan GR. Improved survival of children and adolescents with sickle cell disease. Blood 2010;115:3447-3452.

17. Platt OS, Brambilla DJ, Rosse WF, Milner PF, Castro O, Steinberg MH, Klug PP. Mortality in sickle cell disease. Life expectancy and risk factors for early death. New Engl J Med 1994;330:1639-1644.

18. Vichinsky EP, Neumayr LD, Earles AN, Williams R, Lennette ET, Dean D, Nickerson O, Orringer E, McKie V, Bellevue R, Daeschner C, Manci EA. Causes and outcomes of the acute chest syndrome in sickle cell disease. National Acute Chest Syndrome Study Group. New Engl J Med 2000;342: $1855-1865$

19. Powars DR, Chan LS, Hiti A, Ramicone E, Johnson C. Outcome of sickle cell anemia: A 4-decade observational study of 1056 patients. Medicine 2005;84:363-376.

20. Fitzhugh CD, Lauder N, Jonassaint JC, Telen MJ, Zhao X, Wright EC, Gilliam FR, De Castro LM. Cardiopulmonary complications leading to premature deaths in adult patients with sickle cell disease. Am J Hematol 2010;85:36-40.

21. Gardner K, Bell C, Bartram JL, Allman M, Awogbade M, Rees DC, Ervine M, Thein SL. Outcome of adults with sickle cell disease admitted to critical care-Experience of a single institution in the UK. Br J Haematol 2010;150:610-613.

22. Charache S, Terrin ML, Moore RD, Dover GJ, Barton FB, Eckert SV, McMahon RP, Bonds DR. Effect of hydroxyurea on the frequency of painful crisis in sickle cell anemia. Investigators of the Multicenter Study of Hydroxyurea in Sickle Cell Anemia. New Engl J Med 1995:332:1317-1322.

23. Ferster A, Vermylen C, Cornu G, Buyse M, Corazza F, Devalck C, Fondu P, Toppet M, Sariban E. Hydroxyurea for treatment of severe sickle cell anemia: A pediatric clinical trial. Blood 1996;88:1960-1964.

24. Gulbis B, Haberman D, Dufour D, Christophe C, Vermylen C, Kagambega F, Corraza F, Devalck C, Dresse MF, Hunnick K, Klein A, Le PQ, Loop M, Maes P, Philippet P, Sariban E, Van Geet C, Ferster A. Hydroxyurea for sickle cell disease in children and for prevention of cerebrovascular events: The Belgian experience. Blood 2005; 105:2685-2690.

25. Ware RE. How I use hydroxyurea to treat young patients with sickle cell anemia. Blood 2010;115:5300-5311.

26. Vermylen C, Cornu G, Ferster A, Brichard B, Ninane J, Ferrant A, Zenebergh A, Maes P, Dhooge C, Benoit Y, Beguin Y, Dresse MF, Sariban E. Haematopoietic stem cell transplantation for sickle cell anemia: The first 50 patients transplanted in Belgium. Bone Marrow Transplant 1998;22:1-6.

27. Walters MC, Patience M, Leisenring W, Eckman JR, Scott JP, Mentzer WC, Davies SC, Ohene-Frempong K, Bernaudin F, Matthiews DS, Storb R, Sullivan KM. Bone marrow transplantation for sickle cell disease. New Engl J Med 1996:335:369-376.

28. Panepinto JA, Walters MC, Carreras J, Marsh J, Bredeson CN, Gale RP, Hale GA, Horan J, Hows JM, Klein JP, Pasquini R, Roberts I, Sullivan K, Eapen M, Ferster A. Non-malignant marrow disorders working committee, center for international blood and marrow transplant research. matched-related donor transplantation for sickle cell disease: Report from the center for international blood and transplant research. Br J Haematol 2007; 137:479-485.

29. Bernaudin F, Socie G, Kuentz M, Chevret S, Duval M, Bertrand Y, Vannier IP, Yakouben K, Thuret I, Bordigoni P, Fischer A, Lutz P, Stephan JL, Dhedin N, Plouvier E, Margueritte G, Bories D, Verlhac S, Esperou H, Coic L, Vernant JP. Gluckman E; SFGM-TC. Long-term results of related myeloablative stemcell transplantation to cure sickle cell disease. Blood 2007;110:2749-2756.

30. Dedeken L, Lê P-Q, Azzi N, Brachet C, Heijmans C, Huybrechts S, Devalck C, Rozen L, Ngalula M, Ferster A. Hematopoietic stem cell transplantation for severe sickle cell disease in childhood: A single centre experience of 50 patients. Br J Haematol 2014;165:402-408.

31. Rees DC, Olujohungbe AD, Parker NE, Stephens AD, Telfer P, Wright J. British committee for standards in haematology general haematology task force by the sickle cell working party. Guidelines for the management of the acute pain crisis in sickle cell disease. Br J Haematol 2003;120:744-752.

32. de Montalembert M, Brousse V, Elie C, Bernaudin F, Shi J, Landais P. French study group on sickle cell disease. Long term hydroxyurea treatment in children with sickle cell disease: Tolerance and clinical outcomes. Haematologica 2006;91:125-128

33. de Montalembert M, Ferster A, Colombatti R, Rees DC, Gulbis B. European network for rare and congenital anaemias. ENERCA clinical recommendations for disease management and prevention of complications of sickle cell disease in children. Am J Hematol 2011:86:72-75.

34. Yawn BP, Buchanan GR, Afenyi-Annan AN, Ballas SK, Hassell KL, James AH, Jordan L, Lanzkron SM, Lottenberg R, Savage WJ, Tanabe PJ, Ware RE, Murad MH, Goldsmith JC, Ortiz E, Fulwood R, Horton A, John-Sowah J. Management of sicke cell disease: Summary of the 2014 evidence-based report by expert panel members. JAMA 2014;312:1033-1048.

35. Gill FM, Sleeper LA, Weiner SI, Brown AK, Bellevue R, Grover R, Pegelow CH, Vichinsky E. Clinical events in the first decade in a cohort of infants with sickle cell disease. Coopperative study of sikle cell disease. Blood 1995;86:776-783.

36. Lanzkron S, Carroll CP, Haywood C, Jr. Mortality rates and age at death from sickle cell disease: U.S., 1979-2005. Public Health Rep 2013;128:110-116.

37. Strousse JJ, Lanzkron S, Beach MC, Haywood C, Park H, Witkop C, Wilson RF, Bass EB, Segal JB. Hydroxyurea for sickle cell disease: A systematic review for efficacy and toxicity in children. Pediatrics 2008;122:1332-1342

38. Wang WC, Ware RE, Miller ST, Iyer RV, Casella JF, Minniti CP, Rana S, Thornburg CD, Rogers ZR, Kalpatthi RV, Barredo JC, Brown RC, Sarnaik SA, Howard TH, Wynn LW, Kutlar A, Armstrong FD, Files BA, Goldsmith JC, Waclawiw MA, Huang X, Thompson BW, BABYHUG investigators. Hydroxycarbamide in very young children with sickle-cell anemia: A multicentre, randomised, controlled trial (BABY HUG). Lancet 2011;377:1663-1672.

39. Thornburg CD, Files BA, Luo Z, Miller ST, Kalpatthi R, Iyer R, Seaman P, Lebensburger J, Alvarez O, Thompson B, Ware RE, Wang WC, BABYHUG Investigators. Impact of hydroxyurea on clinical events in the BABYHUG trial. Blood 2012;120:4304-4310.

40. Steinberg MH, Barton F, Castro O, Pegelow CH, Ballas SK, Kutlar A, Orringer E, Bellevue R, Olivieri N, Eckman J, Varma M, Ramirez G, Adler B, Smith W, Carlos T, Ataga, DeCastro L, Bigelow C, Saunthararajah Y, Telfer M, Vichinsky E, Claster S, Shurin S, Bridges K, Waclawiw M, Bonds D, Terrin M. Effect of hydroxyurea on mortality and morbidity in adult sickle cell anemia: Risks and benefits up to 9 years of treatment. JAMA 2003;289:1645-1651.

41. Steinberg MH, McCarthy WF, Castro O, Ballas SK, Armstrong FD, Smith W, Ataga K, Swerdlow P, Kutlar A, DeCastro L, Waclawiw MA. Investigators of the multicenter study of hydroxyurea in sikle cell anemia and MSH patients' follow-up. The risks and benefits of long-term use of hydroxyurea in sickle cell anemia: A 17.5 year follow-up. Am J Hematol 2010;85:403-408

42. Gulbis B, Ferster A, Vermylen C, Dresse MF, Vanderfaeillie A, Delannoy A, Labarque V, Philippet P, Kentos A, Sztern B, Deprijck B, Vertongen F. Red blood cell disorders subcommittee of the Belgian Haematological Society. An estimation of the incidence and demographic picture of the major hemoglobinopathies in Belgium (from a confidential inquiry). Hemoglobin 2008:32:279-285.

43. Miller AC, Gladwin MT. Pulmonary complications of sickle cell disease. Am J Respir Crit Care Med 2012;185:54-65.

44. Gladwin MT, Barst RJ, Gibbs JS, Hildesheim M, Sachdev V, Nouraie M, Hassell KL, Little JA, Schraufnagel DE, Krishnamurti L, Novelli E, Girgis RE, Morris CR, Berman Rosenzweig, Lanzkron DB, Castro S, . Taylor JG 6th, Goldsmith JC, Kato GJ, Gordeuk VR, Machado RF, walk-PHaSST investigators and Patients. Risk factors for death in 632 patients with sickle cell disease in the United States and United Kingdom. PLoS One 2014;9:e99489. doi:10.1371/journal.pone.0099489. 